\title{
ШЛЯХИ ФОРМУВАННЯ КЛІНІЧНОЇ КОМПЕТЕНТНОСТІ У СТУДЕНТІВ НА КАФЕДРІ ДИТЯЧОЇ ХІРУРГІЇ ІЗ ЗАСТОСУВАННЯМ РІЗНИХ МОДЕЛЕЙ ВИКЛАДАННЯ
}

I. М. Бензар

Нацуіональний медичний університет імені О. О. Богомольия

\section{WAYS OF FORMING CLINICAL COMPETENCE ACCOMPLISHMENT IN STUDENTS ON PEDIATRIC SURGERY DEPARTMENT USING DIFFERENT TEACHING MODELS}

I. M. Benzar

\author{
National Medical University by O. O. Bohomolets
}

\begin{abstract}
У статті розглянуто дві основні сучасні моделі викладання клінічних спеціальностей. Перша модель пропонує для використання у практиці клінічного заняття п'яти мікронавиків: отримання інформації, отримання документальних підтверджень, навчання загальних правил, перевірка підтверджуючих доказів, виправлення помилок. Піраміда Міллера описує досягнення клінічної компетентності спеціально для організації навчання клінічних дисциплін. У піраміді нижні два рівні відображають лише когнітивність або знання (знає, знає як). Верхні два рівні випробовують поведінку: чи може студент впровадити знання в практику (показує і робить).

Two models of clinical teaching are considered in the article. First model offers to practice five microskills for clinical teaching: get a commitment, probe for supporting evidence, teach general rules, reinforce what was right, correct mistakes. Miller's pyramid describes the competences identified for the healthcare education specially. In the pyramid, the lower two levels only test cognition or knowledge (knows and knows how). The upper two levels test behavior: can students apply what they know into practice (shows and does).
\end{abstract}

Вступ. Сучасна система медичної освіти повинна бути спрямована на створення і підтримку середовища навчання, удосконалення навчання шляхом проведення оцінювання, підтримки і моніторингу навчального процесу, управління особистим і професійним розвитком, а також неперервного професійного розвитку в якості викладача. За вимогами часу, в медичній освіті впроваджуються новітні технології навчання. Термін “технологія” запозичений із сфери виробництва, де він означає сукупність методів, впровадження яких забезпечує істотне підвищення вірогідності отримання запланованого результату [1]. Саме з цим відтінком підвищення ефективності процесу навчання, орієнтованого на максимально однозначно описаний конкретний результат, термін "технологія освіти" почав першочергово використовуватися в теорії освіти [2]. Основою для розробки і впровадження нових технологій навчання можна вважати фундаментальне визначення Асоціації з педагогічних комунікацій і технологій США: педагогічна технологія

(ㄱ) I. М. Бензар
$€$ комплексним, інтегрованим процесом, який включає людей, ідеї, засоби і способи організації діяльності для аналізу проблем, які охоплюють всі аспекти засвоєння знань. Викладання клінічних спеціальностей має свої особливості, для забезпечення новітніх технологій найбільш прийнятними на сьогодні можна вважати дві технологічні моделі: метод п'яти мікронавиків та метод піраміди Міллера.

Метою даної роботи $€$ впровадження згаданих моделей у практику викладання клінічних дисциплін на прикладі викладання дитячої хірургії.

Основна частина. Особливістю вивчення клінічних предметів $€$ використання клінічного середовища, якому властиві три основні характеристики:

1. Фізичне середовище. Студенти спілкуються 3 пацієнтами 3 різними захворюваннями (різноманітність клінічних випадків впливає на формування навиків). На базі багатопрофільної клініки НДСЛ “ОХМАТДИТ" ця особливість виражена особливо яскраво, враховуючи різноманітність патологій, як набутих захворювань, так і вроджених вад розвитку. Більше того, окремі вроджені вади, синдромальні 
патології зустрічаються надзвичайно рідко (з частотою 1-2 випадки на 50-100 тисяч живих новонароджених), що зумовлює необхідність творчого мислення у студента, а також вміння виділяти не нозологічні форми, а синдроми, що в подальшому полегшить роботу зі спеціальними літературними джерелами, забезпечить вміння обрати необхідного консультанта, не виключено, із залученням іноземних колег, отримання навиків сучасних методів підтвердження діагнозу, включаючи телемедицину. Для забезпечення комфортного існування у такому особливому фізичному середовищі необхідно достатньо місця для індивідуального розбору пацієнтів і зворотного зв’ язку.

2. Емоційне середовище. Студенти повинні відчувати себе бажаними в команді. Викладачі і співробітники повинні бути доступними у спілкуванні. Зворотний зв'язок повинен бути частим і конструктивним. Особливістю роботи у дитячій клініці є необхідність спілкування не лише з маленькими пацієнтами, а також з їх батьками. У цьому відношенні студент повинен бути максимально коректний і завжди впевнений у допомозі викладача, медичних працівників для налагодження двостороннього контакту. Традиційний підхід викладання і спілкування з допомогою приниження ніколи не повинен бути використаний.

3. Інтелектуальний клімат. Викладачі повинні моделювати інтелектуальну зацікавленість і науково обгрунтоване прийняття рішення. Достатньо часу для спостереження, дискусії і запитань. Інформаційні ресурси повинні бути доступними. Клінічне мислення формується з допомогою недиференційованих клінічних випадків.

В аспекті особливостей клінічного середовища розглянемо дві моделі викладання клінічних спеціальностей, які набули популярності за останній період часу: метод п’яти мікронавиків та піраміда Міллера.

Метод п'яти мікронавиків [3]. Цей метод часто називають “однохвилинним наставником”, ніби підкреслюючи, як швидко його можна застосувати. Він являє собою набір базових навиків викладання, які можуть бути використані при розгляді випадку, щойно представленого викладачем. Набір навиків $€$ ефективним для підвищення успішності студентів.

Студенту необхідно прийняти рішення стосовно діагнозу, обстеження або лікування. Приймаючи рішення, студент відчуває відповідальність за своє власне навчання і стає більш мотивованим до отримання знань. Отримання основної інформації у даному випадку походить від пацієнта, його родичів, медичної документації. У цьому плані необхідно забезпечити фізичне середовище навчання.
Перевірити підтверджуючі докази. Представлення студентом обгрунтування свого рішення дає важливу інформацію щодо їх базових знань і клінічних вмінь. Це також приводить студентів до межі їх можливостей, де вони максимально проявляються та студент інтенсивно мислить і максимально аналізує базові знання.

Навчання загальних правил - яку ключову інформацію повинен винести студент із кожного конкретного випадку. Закріпіть те, що було правильним, щоб стимулювати подальшу роботу в заданому напрямку. Для реалізації даного завдання необхідне комфортне емоційне середовище, оскільки при формулюванні висновків студенту нерідко доводиться звертатися до викладача, а також до лікуючого лікаря, завідувача відділення.

Виправляйте помилки. Студенти часто не усвідомлюють своїх помилок і їм потрібен зворотний зв'язок і рекомендації для покращення роботи. Для реалізації даного завдання необхідний комфортний інтелектуальний клімат.

При використанні методу п'яти мікронавиків при опрацюванні окремої клінічної ситуації, а також при роботі в амбулаторних умовах 50 \% часу студент використовує на оцінку клінічної ситуації, 25 \%-відповіді на запитання викладача і 25 \% - дискусія за темою.

У 1990 році психолог Джордж Міллер запропонував структуру навчання, яка спрямована на досягнення клінічної компетентності майбутніх лікарів [4]. На першому рівні цієї піраміди знаходяться знання (знає), за якою іде компетентність (знає як), представлення (показує як) і дія (виконує). У цій структурованій схемі автор пропонує взаємозв' язок між отриманими теоретичними знаннями та клінічною практикою, яка у будь-якому випадку повинна базуватися на першому, “найнижчому” рівні піраміди [5]. Основною метою навчання студентів, яке базується на запропонованій моделі, є розвиток клінічного мислення, побудова клінічної ситуації, вміння застосовувати на практиці отримані знання [6].

Для досягнення цієї мети на кафедрі дитячої хірургії застосовуються такі послідовні кроки: тестовий контроль вихідного рівня знань, вирішення клінічних завдань, робота з пацієнтами з наступним розбором запропонованої клінічної ситуації. Тести вихідного рівня включають не лише запитання 3 предмета дитячої хірургії, але йз анатомії, фізіології, патофізіології тощо. Така побудова завдань відображає вертикальну інтеграцію кафедр і дозволяє студентам в подальшому підготуватися до більш глибокого розуміння клінічної ситуації з розумінням патогенезу захворювання. Ви- 
рішення клінічної ситуації в умовах навчальної кімнати - це умовно другий рівень піраміди, який демонструє компетентність студента, оскільки вимагає знання не лише теми практичного заняття, але й інших клінічних знань, отриманих на кафедрах пропедевтики, педіатрії, загальної хірургії, інших клінічних кафедрах та $€$ прикладом горизонтальної інтеграції кафедр. Виявивши, що процес пізнання призупиняється через недостатність знань у студентів, викладач передає необхідну інформацію у формі лекції, конференції, бесіди. На цьому етапі активно використовуються мультимедійні технології, які значно підвищують ефективність засвоєння матеріалу, надають можливість синкретичного навчання, тобто одночасно зорового і слухового сприйняття матеріалу [7].

Третій рівень піраміди - представлення - це робота в клінічній ситуації, безпосередньо з пацієнтом. На даному етапі роль викладача $€$ пасивною, він виконує лише функцію спостерігача, за необхідності - консультує. Викладач не навчає студентів, а виконує функцію стимулювання і координації їх роботи, а також функцію управління засобами навчання. Забезпечення виконання третього рівня піраміди може досягатися різними способами, зокрема:

- розгляд конкретної клінічної ситуації у відділенні стаціонару за участі пацієнтів, батьків, медичного персоналу;

- робота із заготовленою клінічною ситуацією за участі групи студентів та викладача, який виконує на даному етапі лише функцію спостерігача;

- опрацювання заданої клінічної ситуації на навчальних тренажерах.

На цьому етапі педагогічна майстерність викладача полягає в тому, щоб відібрати необхідний зміст, застосувати оптимальні методи і засоби навчання відповідно до програми і поставлених педагогічних цілей, а також у можливості максимального впровадження методів стимуляційного навчання.

Найвищий щабель піраміди - виконує - здійснюється студентом шляхом постановки діагнозу та призначення лікування. На цьому етапі студент демонструє своє вміння “мислити як лікар", тобто оволодіння методикою клінічного мислення, а також свою компетентність, встановлюючи діагноз та в подальшому призначаючи лікування, враховуючи не лише нозологічну одиницю, а конкретного пацієнта, його вік, супутні захворювання, обмеження використання різних методик, враховуючи вікові обмеження та преморбідний фон. Така методика є ефективною і багатогранною при використанні на базі багатопрофільного стаціонару, яким є клініка "ОХМАТДИТ”. За- вершальна частина практичного заняття передбачає загальне обговорення, в процесі якого викладач націлює студентів на доведення істинності своїх рішень (встановлення діагнозу, проведення диференційного діагнозу, складання плану лікування тощо). В результаті виникає дискусія, в ході якої від студентів вимагається обгрунтування, логічна аргументація, підведення до вирішення завдання.

Розглянувши особливості технологічних методик навчання, можна констатувати, що метод п'яти мікронавиків незамінний для викладача у ході моделювання і оцінки конкретних клінічних ситуацій, а метод піраміди Міллера дозволяє фундаментально підійти до моделювання кожного практичного заняття на клінічній кафедрі.

Отже, обидві розглянуті методики навчання можуть використовуватися на клінічних кафедрах для забезпечення високої якості навчання. Вони не замінюють, а взаємодоповнюють одна одну у досягненні основної мети навчання - досягнення клінічної компетентності студента. Характеристики клінічної компетентності є практичним відображенням піраміди Міллера, яке лежить не лише в основі побудови практичного заняття, а в основі отримання і практичного використання знання лікаря. Перший рівень компетентності - теоретичні знання основних понять, розуміння окремих принципів, вміння виділяти факти (симптоми і синдроми). Другий рівень - вміння застосовувати й інтерпретувати знання I рівня. Третій рівень - діагностика за умови типового перебігу захворювання. Четвертий рівень - високий рівень активного застосування знань, активна позиція щодо тактики ведення пацієнта, вміння застосувати отримані знання до конкретного пацієнта, конкретної клінічної ситуації.

Висновки: 1. Перевага застосування новітніх технологічних моделей навчання на базі багатопрофільного стаціонару полягає в тому, що студенти набувають досвіду індивідуальної роботи при організації і плануванні пізнавальної діяльності, формулюванні і вирішенні клінічних проблем, моделюванні засобів набування і переробки інформації.

2. Впровадження різних моделей навчання не заперечують, а взаємодоповнюють одна одну.

3. Метод п'яти мікронавиків має переваги при організації роботи поліклінічних занять і опрацюванні окремих клінічних ситуацій.

4. Метод піраміди Міллера можна покласти за основу в процесі навчання на базі багатопрофільного стаціонару і більш широкої організації роботи клінічної кафедри. 


\section{ВДОСКОНАЛЕННЯ ВИЩОЇ МЕДИЧНОЇ ОСВІТИ}

\section{Література}

1. Norcini J. Work based assessment / J. Norcini // B.M.J.-2003.-No 326.-P. 753-755.

2. McKinley R. Model for directly assessing and improving competence and performance in revalidation of clinicians / R. McKinley, R. Fraser, R. Baker // B.M.J. -2001. - No 322. P. 712-715.

3. Evidence-based Office Teaching - The Five-step Microskills Model of Clinical Teaching Fam / S. Parrott, A. Dobbie, H. Chumley, J. W. Tysinger // Med. - 2006. Vol.38(3).-P. 164-167.

4. Соколов В. М. Инновационные технологии в образовании: стимулы и препятствия / В. М. Соколов // Вестник ННГУ. -2005.-Выпуск 1(6).-С. 202-206.
5. Кларин М. В. Инновации в мировой педагогике: обучение на основе исследования, игры и дискуссии (Анализ зарубежного опыта) / М. В. Кларин. - Рига : НПЦ “ЭКсперимент", 1995.-176 c.

6. Осин А. В. Мультимедиа в образовании: контекст информатизации. / А. В. Осин. - М. : Агентство "Издательский сервис", 2004.-320 с.

7. Miller G. E. The assessment of clinical skills /competence/ performance / G. E. Miller // Acad. Med. - 1990. - Vol. 65. P. 63-67. 